\title{
Evaluation of School Effectiveness of Secondary Education System: Comparative view of Public and Private Institutions of Pakistan
}

\author{
Dr. Mukhtar Ahmed, Ph.D \\ Regional Director (Gujranwala), \\ Allama Iqbal Open University, Islamabad \\ rd_gujranwala@aiou.edu.pk \\ Tariq Mahmood \\ PhD Research Fellow, University of Education, Division of Education \\ College road Town ship, Lahore, Pakistan \\ Corresponding Author: tariq_903@hotmail.com

\section{Muhammad Shams Mhyuddin} \\ M. Phil Scholar, Al-Khair University AJK \\ Muhammad Amin Ghuman \\ PhD Scholar, International Islamic University Islamabad \\ Senior Subject Specialist GHSS Eminabad (Gujranwala)
}

Doi:10.5901/jesr.2013.v4n3p121

\section{Abstract}

\begin{abstract}
The intention of this study was to examine the school effectiveness in public and private schools at secondary level. The study was designed to see the effectiveness of public and private schools. The objectives of the study were: To find out the effectiveness of public secondary schools of Lahore city. To find out the effectiveness of private secondary schools of Lahore city. To compare the effectiveness of public and private schools of Lahore city. To suggest measures to improve the effectiveness of public and private secondary schools. To fulfill these objectives a questionnaire on school effectiveness was developed by the researchers. Computer program SPSS (statistical package for social sciences) was used to analyze the data. Majority of the private schools are satisfied with their communication skills, about their management activities, staff development and their performance. Private schools are satisfied about their interpersonal relationships with their teaching staff and their teaching staff also agrees that private schools perform their duties and responsibilities in better way. Overall results show that both Govt. and private schools are performing well but private schools are performing very well as compared to Govt. at the secondary level.
\end{abstract}

\section{Introduction}

An organization is said to be effective if it is doing the right thing in the right way, while striving to achieve its objectives using its resources optimally, i.e., economically, efficiently and effectively. Erlendsson (2002) defines effectiveness as: "The extent to which objectives are met".

It is common sense that an effective school is roughly the same as "good" school. School, being a social instrument of growth and development, how effectively a school functions is a question of national interest right from the top level planners to the parents who send their children to the schools. Though the level of expectation could vary at different persons, every one would expect that the school effectiveness should be optimum at a given time and situation, the academic achievement and reputation of the school may both be considered as the explicit or practical indicates of its effectiveness or outcome. The performance of the school can be expressed as the output of the school, which in turn is measured in terms of the average achievement of the pupils at the end of a period of formal schooling. 
But the outcomes to a great extent depend upon a number of internal factor such as the principle's leadership style and his involvement in the school activity, teacher's involvement and performance, the student's involvement and the quality of their performance the availability and utilization of resources, social acceptance of the school and so on.

Laggard (1991) documented that,

"An effective school has a climate that is purposeful and orderly, has high standards of performance, has a clear sense of mission, has strong goal and achievement oriented leadership and a staff that is involved in planning".

As the success of any enterprise depends upon the quality of its leadership, the effectiveness of the school too depends upon the leadership style of its principal or head master. The head teacher acts as the leading professional in a school and as an officer of the local authority. He/she provides appropriate vision, leadership and direction to ensure high standards of education for all the children and young people in their care so that they can become successful learners, confident individuals, responsible citizens and effective contributors. To achieve this, the head teacher works with and is accountable to others to ensure that the school is organised and managed to meet its aims and targets, and is a creative, disciplined learning environment. In so doing, the head teacher works with a range of others - staff, children and young people, parents, local community members, voluntary organisations, local authority officers and other agencies involved in services for children and young people and their families. Each school will present different challenges reflecting the school's circumstances and the communities they serve.

The cooperation of teaching staff to head teacher in the management activities of school like maintenance of records of all types and facilitate the students, is very important. Without the proper and healthy support of teaching staff, it is difficult for head teacher to execute the management activities (management of physical and work resources, maintenance of school building etc) of the school.

\section{Concept of school effectiveness}

School effectiveness has been one of the major concerns of practitioners and policy makers, throughout the world. The notion of school effectiveness encompasses students' academic achievements and development of their personality together with the development of teachers

The concept of effective school was introduced in America in 1960s. A number of American universities and research institutes worked on this issue. Coleman (1966) is of the view that difference of school does not make a significance difference in student's achievement. The stress was on family and the environment in which the children (student) live, as it will have substantial influence on achievement and subsequent performance. This leads to the opinion that schools and teachers make no difference. This research accepted that school plays an insignificant portion in the education of the student, curriculum was considered to be considerably important to meet the child's requirement. This was the thinking in 60s and curriculum provision was considered as the main tier and function of schools continuing with this thinking was that the teachers are not involved in the classrooms; and no linkage was developed between the teaching style and curriculum development (Hopkins, 1987).

Contrary to 1960s, during 1970s, 1980s and gradually, the consideration of an effective contribution to a student's achievement assumed education became an important role and started drawing greater attention of the research scholar. Bookover et al. (1979) supported the concept that schools could make a difference, to a child's attainment.

Reynolds (1976) started work in England on 'School Difference Research'. The results provided and established the concept of school effectiveness. He published his findings, in an article in the New Society Journal. His work was continued by Edmonds (1978), who identified factors of effective schools, that, he found made a difference to performance and achievement.

\section{School effectiveness in Pakistan}

School effectiveness, in Pakistan, has been viewed in different contexts. Educational plans have no clear-cut provision on school effectiveness. Although improving curriculum and teacher's training has been the main thrust of all major policies, yet, school effectiveness is a major concern from two standpoints: quality of teaching and outcomes of students.

In Pakistan, school effectiveness is generally, measured by results obtained by students at various levels. The higher the number of grades and the pass percentage, more effective the school is considered. This is, however, not the correct approach, as school effectiveness should deal with overall development of student personality, whereas 
scholastic achievement, teacher's training, teacher taught relationship are basic components of school development, as a result of Professional Development. While making the pass percentages as a standard for school effectiveness, many factors may be overlooked. There are possibilities that "Good" outcome may be done to supplemental coaching outside the school, by those who can afford this, which indirectly indicates that obtaining good results is not because of teaching at the school but is dependent on the "paying capacity" of those who can afford for coaching outside the school hours.

The above considerations lead us to the inference, that school effectiveness is judged only by grades obtained rather than more effective elements leading to holistic development of children. Factors such as developing the learning skills, building confidence to face life, attitude and perception towards life, etc, or in other words the intellectual growth stands to be neglected (Siddiqui, 2007).

\section{School Effectiveness in Public Schools}

Students in public schools have math scores that are just as good if not better than those of students in private schools, according to a new national study. The research focused across several years on 9,791 secondary school students.

"These data provide strong, longitudinal evidence that public schools are at least as effective as private schools in boosting student achievement," said researcher Christopher Lubienski of the University of Illinois. Combined with other, yet-unpublished studies of the same data, which produced similar findings, "we think this effectively ends the debate about whether private schools are more effective than publics," said Lubienski, whose research has dealt with all aspects of alternative education. This is important, he said, because many current reforms, such as "No Child Left Behind" charter schools and vouchers for private schools, are based on the assumption that private schools offer better education than public schools.

A previous study by the Lubienskis heated up controversy over the quality of private school education. It showed that students' math scores are better at public schools than at private schools, when controlling for socioeconomic status, but some critics said that study failed to show the possible effect over time of different types of schooling.

The most recent data available for the University of Illinois study was gathered in 2004, in the spring of the students' fifth-grade year. The sample used for the study included students in 1,531 schools (1,273 public, 140 Catholic and 118 other private schools).

After controlling for demographic differences among students and schools, the researchers found that public school students began kindergarten with math scores roughly equal to those of their Catholic school peers. By fifth grade, however, they had made significantly greater gains, equal to almost an extra half year of schooling, Sarah Lubienski said.

Public school students also "rivaled the performance of students in other (non-Catholic) private schools," the researchers wrote. After adjusting for demographics and initial kindergarten scores, they found that achievement gains between kindergarten and fifth grade were roughly equal.

"School type alone doesn't explain very much of why these scores vary ... in truth, whether the school is public or private doesn't seem to make that much difference," Sarah Lubienski said.

The researchers go on to write that they "personally see private schools as an integral part of the American system of education" and "there are many valid reasons why parents choose private schools and why policymakers may push for school choice."

\section{Methodology of the Study}

Data was analyzed using SPSS software and main results were found as under:

\subsection{Opinion of Students about their School}

Proceeding table shows the opinion of students about their school

\begin{tabular}{|c|c|c|c|c|c|c|c|}
\hline $\mathrm{Sr}$ & \multirow{2}{*}{ Statement } & \multirow{2}{*}{ School } & SA & A & UD & $\mathrm{D}$ & $\mathrm{SD}$ \\
\hline & & & $\%$ & $\%$ & $\%$ & $\%$ & $\%$ \\
\hline & d reputation in the locality. & G & 64.0 & 30.4 & 3.6 & 1.3 & 0.7 \\
\hline & ppportunities for sports, games and & G & 44.7 & 40.7 & $\begin{array}{c}13.5 \\
6.6\end{array}$ & 2.7 & $\begin{array}{l}0.4 \\
5.3\end{array}$ \\
\hline
\end{tabular}




\begin{tabular}{lcccccc}
\hline dramatics. & $\mathrm{P}$ & 33.3 & 55.3 & 4.7 & 6.0 & 0.7 \\
The various activities in the school are carried out as per the & $\mathrm{G}$ & 38.7 & 36.0 & 12.6 & 8.7 & 4.0 \\
3. & $\mathrm{P}$ & 27.3 & 50.0 & 10.0 & 12.0 & 0.7 \\
schedule. & $\mathrm{G}$ & 17.3 & 46.7 & 8.7 & 25.3 & 2.0 \\
4. The school has adequate modern facilities. & $\mathrm{P}$ & 22.0 & 48.0 & 9.3 & 18.7 & 2.0 \\
\hline
\end{tabular}

Above table shows the opinion of students about their school. First statement shows that $94.4 \%$ of govt and $82.0 \%$ of private students agree that school maintains good reputation in the locality where as $2.0 \%$ govt and $4.7 \%$ private students are disagree. In second statement $85.4 \%$ govt and $88.6 \%$ private students agree that school provides good opportunities for sports, games and dramatics where as $8.0 \%$ govt and $6.7 \%$ private students are disagree. Third statement shows that, $74.7 \%$ of govt and $77.3 \%$ private students agree that various activities in the school are carried out as per the schedule where as $12.7 \%$ govt and $12.7 \%$ private students are disagree. In forth statement, $64.0 \%$ govt and $70.0 \%$ private students agree that school has adequate modern facilities where as $27.3 \%$ govt and $20.7 \%$ private students are disagree.

\subsection{Opinion of Students about their School}

Proceeding table shows the opinion of students about their school

\begin{tabular}{cccccccc}
\hline Sr & \multicolumn{1}{c}{ Statement } & School & SA & A & UD & D & SD \\
\cline { 5 - 8 } \# & & $\%$ & $\%$ & $\%$ & $\%$ & $\%$ \\
5. The school is open to all classes. & $\mathrm{G}$ & 51.3 & 34.7 & 6.6 & 6.7 & 0.7 \\
& & $\mathrm{P}$ & 26.0 & 31.3 & 6.7 & 22.7 & 13.3 \\
& & $\mathrm{G}$ & 12.7 & 39.3 & 14.0 & 22.0 & 12.0 \\
6. & There is no favoritism in the school. & $\mathrm{P}$ & 26.7 & 38.0 & 8.6 & 20.7 & 6.0 \\
& Students think that school prepares them for the & $\mathrm{G}$ & 36.7 & 40.7 & 15.3 & 5.3 & 2.0 \\
7. & $\mathrm{P}$ & 57.0 & 33.6 & 4.0 & 4.7 & 0.7 \\
\hline
\end{tabular}

Above table shows the opinion of students about their school. First statement shows that $86.0 \%$ of govt and $57.3 \%$ of private students agree that their school is open to all classes where as $7.4 \%$ govt and $36.0 \%$ private students are disagree. In second statement $52.0 \%$ govt and $64.7 \%$ private students agree that there is no favoritism in the school where as $34.0 \%$ govt and $26.7 \%$ private students are disagree. Third statement shows that $77.4 \%$ of govt and $90.6 \%$ private students agree that students think that school prepares them for the future occupation where as $7.3 \%$ govt and $5.4 \%$ private students are disagree.

\subsection{Opinion of Students about their Head Teacher}

Proceeding table shows the opinion of students about their head teacher

\begin{tabular}{|c|c|c|c|c|c|c|c|}
\hline $\mathrm{Sr}$ & \multirow{2}{*}{ Statement } & \multirow{2}{*}{ School } & SA & A & UD & $\mathrm{D}$ & SD \\
\hline \# & & & $\%$ & $\%$ & $\%$ & $\%$ & $\%$ \\
\hline \multirow{3}{*}{1.} & \multirow{2}{*}{ Head Teacher is punctual. } & G & 44.0 & 48.0 & 4.6 & 2.7 & 0.7 \\
\hline & & $\mathrm{P}$ & 46.7 & 46.0 & 4.6 & 2.7 & 0.0 \\
\hline & \multirow{2}{*}{ Head Teacher follows rules and regulations. } & G & 36.7 & 45.3 & 12.6 & 4.7 & 0.7 \\
\hline 2. & & $\mathrm{P}$ & 52.7 & 42.7 & 3.3 & 1.3 & 0.0 \\
\hline \multirow{2}{*}{3.} & \multirow{2}{*}{$\begin{array}{l}\text { Head Teacher never compromises } \\
\text { In disciplinary work }\end{array}$} & G & 31.3 & 42.7 & 7.3 & 14.0 & 4.7 \\
\hline & & $P$ & 39.6 & 42.3 & 10.7 & 6.7 & 0.7 \\
\hline \multirow{2}{*}{4.} & \multirow{2}{*}{$\begin{array}{l}\text { Students can approach head teacher } \\
\text { when they are in need. }\end{array}$} & G & 25.3 & 38.0 & 13.4 & 17.3 & 6.0 \\
\hline & & $P$ & 53.3 & 36.7 & 3.3 & 4.0 & 2.7 \\
\hline
\end{tabular}

Above table shows the opinion of students about their head teacher. In first statement, $92.0 \%$ of govt and $92.7 \%$ private students agree that their head teachers is punctual where as 3.4\% govt and $2.7 \%$ private students are disagree. Second statement shows that, $82.0 \%$ govt and $95.4 \%$ private students agree that head Teacher follows rules and regulations where as $5.4 \%$ govt and 1.3\% private students are disagree. In third statement, $74.0 \%$ of govt and $81.9 \%$ private 
students agree that head teacher never compromises in disciplinary matters, where as $18.7 \%$ govt and $7.4 \%$ private students are disagree. Forth statement shows that $63.3 \%$ govt and $90.0 \%$ private students agree that students can approach head teacher when they are in need where as $23.3 \%$ govt and $6.7 \%$ private students are disagree.

\subsection{Opinion of Students about their Head Teacher}

Proceeding table shows the opinion of students about their head teacher

\begin{tabular}{|c|c|c|c|c|c|c|c|}
\hline $\mathrm{Sr}$ & \multirow{2}{*}{ Statement } & \multirow{2}{*}{ School } & SA & A & UD & $\mathrm{D}$ & SD \\
\hline \# & & & $\%$ & $\%$ & $\%$ & $\%$ & $\%$ \\
\hline & Head teacher motivates teachers to be more & G & 20.0 & 42.0 & 16.6 & 12.7 & 8.7 \\
\hline 5. & innovative. & $P$ & 15.3 & 56.0 & 14.7 & 11.3 & 2.7 \\
\hline & Head teacher helps teachers in arranging and & G & 14.7 & 46.7 & 13.2 & 20.7 & 4.7 \\
\hline 6. & organizing co-curricular activities & $P$ & 27.3 & 55.3 & 6.1 & 8.0 & 3.3 \\
\hline 7. & $\begin{array}{l}\text { The Head Teacher provides adequate facilities for } \\
\text { effective teaching. }\end{array}$ & $\begin{array}{l}G \\
P\end{array}$ & $\begin{array}{l}20.0 \\
38.0\end{array}$ & $\begin{array}{l}53.3 \\
48.0\end{array}$ & $\begin{array}{l}8.1 \\
8.0\end{array}$ & $\begin{array}{c}15.3 \\
5.3\end{array}$ & $\begin{array}{l}3.3 \\
0.7\end{array}$ \\
\hline
\end{tabular}

Above table shows the opinion of students about their head teacher. First statement shows that $62.0 \%$ of govt and 71.3 $\%$ private students agree that head teacher motivates teachers to be more innovative where as $21.4 \%$ govt and $14.0 \%$ private students are disagree. In second statement $\quad 61.4 \%$ govt and $82.6 \%$ private students agree that head teacher helps teachers in arranging and organizing co-curricular activities where as $25.4 \%$ of govt and $11.3 \%$ private students are disagree. Third statement shows that $73.3 \%$ govt and $86.0 \%$ private students agree that the head teacher provides adequate facilities for effective teaching, where as $18.6 \%$ govt and $6.0 \%$ private students are disagree .

\subsection{Opinion of Students about their Teachers}

Proceeding table shows the opinion of students about their teachers

\begin{tabular}{|c|c|c|c|c|c|c|c|}
\hline $\mathrm{Sr}$ & \multirow{2}{*}{ Statement } & \multirow{2}{*}{ School } & SA & A & UD & $\mathrm{D}$ & SD \\
\hline \# & & & $\%$ & $\%$ & $\%$ & $\%$ & $\%$ \\
\hline \multirow[b]{2}{*}{1.} & Teachers use improvised teaching aids & G & 4.7 & 39.3 & 19.4 & 25.3 & 11.3 \\
\hline & in class. & $\mathrm{P}$ & 18.0 & 48.7 & 21.3 & 10.0 & 2.0 \\
\hline \multirow{2}{*}{2.} & Problems of students are sympathetically viewed by & G & 25.3 & 36.0 & 6.0 & 24.0 & 8.7 \\
\hline & the teachers. & $\mathrm{P}$ & 22.0 & 48.0 & 9.3 & 16.0 & 4.7 \\
\hline \multirow{2}{*}{3.} & Teachers organize literary talk to encourage the & G & 19.3 & 40.7 & 12.0 & 26.0 & 2.0 \\
\hline & students. & $\mathrm{P}$ & 32.0 & 50.7 & 12.6 & 4.0 & 0.7 \\
\hline \multirow{2}{*}{4.} & Teachers' emnhasis on discinline & G & 22.0 & 48.0 & 13.3 & 14.0 & 2.7 \\
\hline & i eacriers empmasis on uscipminte. & $\mathrm{P}$ & 38.7 & 51.3 & 6.0 & 4.0 & 0.0 \\
\hline
\end{tabular}

Above table shows the opinion of students about their teachers. In first statement $44.0 \%$ of govt and $66.7 \%$ of private students agree that teachers use improvised teaching aids in class where as $36.6 \%$ govt and $12.0 \%$ private students are disagree. Second statement shows that, $61.3 \%$ govt and $70.0 \%$ of private students agree that problems of students are sympathetically viewed by the teachers where as $32.7 \%$ govt and $20.7 \%$ private students are disagree. In third statement $60.0 \%$ of govt and $82.7 \%$ private students agree that teachers organize literary talk to encourage the students, where as $28.0 \%$ govt and $4.7 \%$ private students are disagree. Forth statement shows that, $70.0 \%$ of govt and $90.0 \%$ private students agree that teachers' emphasis on discipline, where as $16.7 \%$ govt and $4.0 \%$ private students are disagree.

\subsection{Opinion of Students about their Teachers}


Proceeding table shows the opinion of students about their teachers

\begin{tabular}{|c|c|c|c|c|c|c|c|}
\hline $\mathrm{Sr}$ & \multirow{2}{*}{ Statement } & \multirow{2}{*}{ School } & SA & $A$ & UD & $\mathrm{D}$ & SD \\
\hline \# & & & $\%$ & $\%$ & $\%$ & $\%$ & $\%$ \\
\hline \multirow{2}{*}{5.} & \multirow{2}{*}{ Teachers are punctual. } & G & 38.7 & 38.0 & 8.6 & 14.0 & 0.7 \\
\hline & & $P$ & 53.3 & 40.0 & 2.0 & 4.0 & 0.7 \\
\hline \multirow{2}{*}{6.} & Teachers propose places for visit as & G & 12.0 & 36.0 & 3.3 & 24.7 & 24.0 \\
\hline & field trips for students. & $P$ & 26.0 & 46.0 & 2.6 & 18.7 & 6.7 \\
\hline \multirow{2}{*}{7.} & Teachers encourage the students to do socially useful & G & 21.3 & 36.7 & 12.7 & 22.0 & 7.3 \\
\hline & and productive work. & $P$ & 31.3 & 52.7 & 7.3 & 8.0 & 0.7 \\
\hline
\end{tabular}

Above table shows the opinion of students about their teachers. First statement shows that $76.7 \%$ govt and $93.3 \%$ private students agree that teachers are punctual where as $14.7 \%$ govt and $4.7 \%$ private students are disagree. In second statement, $48.0 \%$ of govt and $72.0 \%$ private students agree that teachers propose places for visit as field trips for students where as $48.7 \%$ govt and $25.4 \%$ private students are disagree. Third statement shows that $58.0 \%$ of govt and $84.0 \%$ private students agree that teachers encourage the students to do socially useful and productive work, where as $29.3 \%$ govt and $8.7 \%$ private students are disagree.

\subsection{Opinion of Students about Themselves}

Proceeding table shows the opinion of students about themselves

\begin{tabular}{|c|c|c|c|c|c|c|c|}
\hline $\mathrm{Sr}$ & \multirow{2}{*}{ Statement } & \multirow{2}{*}{ School } & SA & A & UD & $\mathrm{D}$ & SD \\
\hline \# & & & $\%$ & $\%$ & $\%$ & $\%$ & $\%$ \\
\hline \multirow{2}{*}{1.} & \multirow{2}{*}{ Student's participation in the class is encouraging. } & G & 30.0 & 35.3 & 8.7 & 22.7 & 3.3 \\
\hline & & $\mathrm{P}$ & 30.0 & 50.7 & 11.3 & 6.7 & 1.3 \\
\hline \multirow{2}{*}{2.} & \multirow{2}{*}{ Students tend to study when examination come. } & G & 41.3 & 30.7 & 5.3 & 16.7 & 6.0 \\
\hline & & $\mathrm{P}$ & 17.3 & 22.7 & 8.7 & 28.0 & 23.3 \\
\hline \multirow{2}{*}{3.} & \multirow{2}{*}{$\begin{array}{l}\text { Students make use of library books whenever they } \\
\text { are free. }\end{array}$} & G & 18.7 & 37.3 & 10.0 & 21.3 & 12.7 \\
\hline & & $\mathrm{P}$ & 37.3 & 42.7 & 6.0 & 10.7 & 3.3 \\
\hline \multirow{2}{*}{4.} & On the basis of examination results, the bright & G & 18.7 & 46.7 & 11.2 & 14.7 & 8.7 \\
\hline & students are felicitated. & $\mathrm{P}$ & 43.3 & 38.6 & 6.1 & 11.3 & 0.7 \\
\hline
\end{tabular}

Above table shows the opinion of students about themselves. In first statement, $65.3 \%$ of govt and $80.7 \%$ private students agree that student's participation in the class is encouraging where as $26.0 \%$ govt and $8.0 \%$ private students are disagree. Second statement shows that $72.0 \%$ of govt and $40.0 \%$ private students agree that students tend to study when examination come where as $22.7 \%$ govt and $51.3 \%$ private students are disagree. In third statement $56.0 \%$ of govt and $80.0 \%$ private students agree that students make use of library books whenever they are free, where as $34.0 \%$ govt and $14.0 \%$ private students are disagree. Forth statement shows that, $65.4 \%$ govt and $81.9 \%$ private students agree that on the basis of examination results, the bright students are felicitated, where as $23.4 \%$ govt and $12.0 \%$ private students are disagree.

\subsection{Opinion of Students about Themselves}

Proceeding table shows the opinion of students about themselves

\begin{tabular}{clcccccc}
\hline Sr. & \multicolumn{1}{c}{ Statement } & \multirow{2}{*}{ School } & SA & A & UD & D & SD \\
\cline { 4 - 7 }$\#$ & & & $\%$ & $\%$ & $\%$ & $\%$ & $\%$ \\
& & $G$ & 62.3 & 30.0 & 3.0 & 2.7 & 2.0 \\
4. & Students improve knowledge by reading books. & $\mathrm{P}$ & 54.0 & 30.7 & 8.7 & 4.7 & 1.9 \\
& Students have a healthy relationship between teaching & $\mathrm{G}$ & 14.7 & 42.7 & 10.6 & 19.3 & 12.7 \\
5. & and learning. & $\mathrm{P}$ & 29.3 & 48.7 & 12.0 & 10.0 & 0.0 \\
& The high size in class makes it difficult for the students to & $\mathrm{G}$ & 33.3 & 34.7 & 14.7 & 12.0 & 5.3 \\
6. & clear their doubts. & $\mathrm{P}$ & 30.7 & 18.0 & 11.9 & 26.7 & 12.7 \\
\hline
\end{tabular}


Above table shows the opinion of students about themselves. First statement shows that $92.3 \%$ govt and $84.7 \%$ private students agree that students improve knowledge by reading books, where as $4.7 \%$ govt and $6.6 \%$ private students are, disagree. In second statement, $57.4 \%$ govt and $78.0 \%$ of private students agree that students have a healthy relationship between teaching and learning, where as $32.0 \%$ govt and $10.0 \%$ private students are disagree. Third statement shows that $68.0 \%$ govt and $48.7 \%$ private students agree that the high size in class makes it difficult for the students to clear their doubts where as $17.3 \%$ govt and $39.4 \%$ private students are disagree.

\subsection{Final Result}

Proceeding table shows the final result of school effectiveness study.

\begin{tabular}{ccccccc}
\hline & School & $\mathrm{N}$ & Mean & St.d & t.value & Sig \\
\hline \multirow{2}{*}{ Effectiveness } & Public & 150 & 104.1933 & 12.97375 & \multirow{2}{*}{-4.714} & \multirow{2}{*}{065} \\
& Private & 150 & 110.7933 & 11.21498 & & \\
\hline
\end{tabular}

Summry of t.test reveals that t.value is significant at 0.05 level of significance. Hence null Hypothesis stating no significant difference in school effectiveness in public and private schools was rejected.

\section{Conclusion}

The conclusion of the study draws on the basis of the findings of the research study. Majority of the private schools are satisfied with their communication skills, about their management activities, staff development and their performance.

Private schools are satisfied about their interpersonal relationships with their teaching staff and their teaching staff also agrees that private schools perform their duties and responsibilities in better way.

Over all results show that both govt and private schools are performing well but private schools are performing very well as compared to govt at the secondary level. These findings will provide information to the government, educational administrators, policy makers, and school heads interested in increasing the school effectiveness.

Regardless of the school status, a safe working environment, supportive administration and involved teachers are connected with high level of school effectiveness.

At the conclusion of this research the researcher wants to open this fact that most students do not share their responses in a sincere manner. So these insincere responses of the students may affect the results of this research.

The following recommendations are making on the basis of the study.

- Government should probe the reasons for poor effectiveness of public schools.

- Education policy makers and administration should fulfill the basic needs and requirements of head teachers and teachers so that they perform their duties in best possible way.

- Administrators should create a supportive organizational environment which helps to reduce conflicts between teachers and head teachers.

- Public school heads should evaluate their own leadership styles and try to improve them for effective management.

- As the private schools were proved to be more effective, therefore government should encourage private sectors to open secondary schools especially for female students in rural area.

\section{Reference}

Angus, L. (1993) The Sociology of School Effectiveness, British Journal of Sociology of Education.

Bookover, W.B., C. Beady, J. Schweitzer and J. Wisenbaker (1979). School Social Systems and Student Achievement: Schools Can Make a Difference. New York, Prager.

Cheng, V.C. (1996). School Effectiveness and School Based Management. London: The Flamer Press

Coe, R. and Fitz-Gibbon, C.T. (1998) School Effectiveness Research: Criticisms and Recommendations. Oxford Review of Education.

Coleman, J. S. (1966). Equality of Educational Opportunity. Washington D.C.: Department of Health, Education and Welfare in Silver, H. (1994) Good Schools, Effective Schools - Judgments and their Histories. London, Cassell

Creemers, B.P.M. (1994) he History, Value and Purpose of School Effectiveness Studies in D. Reynolds et al (Eds) Advance in School Effectiveness Research and Practice, Oxford: Pergamon.

Dejnozka, E. L. (1983). Educational administration glossary. London, UK: Greenwood Press. 
Edmonds, R. (1978). A Discussion of the Literature and Issues Related to Effective Schooling. Paper prepared for the National Conference on Urban Education,

Cemrel, St Louis . In Hopkins, D., Ainscow, M. and West, M. (1994) School Improvement in an Era of Change. London, Cassell. Eleven Factors for Effective Schools. Retrieved on 3 March, 2011 from http://www.leading-learning.co.nz/school-vision/eleven-factors.html

Erlendsson, J., 2002, Value For Money Studies in Higher Education http://www.hi.is/ joner/eaps/wh_vfmhe.htm accessed 4 January 2002, not available at this address 4 February 2011.

Fitch, L.A. 1988. Perceptual Congruence Between the Principal and Staff and its Relationship to School Effectiveness. proQuest-Dissertation Abstracts.

Fraser, M., 1994, 'Quality in higher education: an international perspective' in Green, D. (Ed.), 1994, What is Quality in Higher Education? pp. 101-111 (Buckingham, Open University press and Society for Research into Higher Education).

Goldstein, H. (1997) Methods in School Effectiveness Research. School Effectiveness and School Improvement.

Goldstein, H. (2001) School effectiveness and educational effectiveness: text in public lecture, University of Bath, Department of Education.

Goldstein, H., Rasbash, J., Yang, M., Woodhouse, G., Pan, H., Nuttall, D. and Thomas, S. (1993) A multi-level analysis of school examination results. Oxford Review of Education.

Goldstein, H. and Spiegelhalter, D. (1996) League tables and their limitations: statistical issues in comparisons of institutional performance-with discussion. Journal of the Royal Statistical Society.

Herman, J. \& Herman, J. (1994). Making Change Happen, California: Crown Press Inc.

Hersey, P. and Blanchard, K.H. 1988. Management of Organizational Behviour. Prentice Hall of India Private Ltd., New Delhi.

Higdon, M.A. 1998. AStudy of Corrrelation between Student Achievement and Effectiveness Schools Correlates in Selected Wyoming High Schools.

Holly, P. and G. Southworth (1989). The Developing School. Lewes, Falmer Press.

Hopkins, D. (1987b). Improving the Quality of Schooling. Lewes, Falmer Press.

Howard Green (2002) Ten Questions for School Leaders National College for School Leadership

James, C and Cannolly, U. (2000). Effective Change in Schools. New York: Routledge Falmer.

Krueger, .E.1995. Parent's Perception of Secondary School Effectiveness.

Lauder, H., Jamieson, I. and Wikeley Felicity (1998) Models of Effective Schools: Limits and Capabilities. In Slee, R. and Weiner, G. with Tomlinson, S. (eds) "School

Effectiveness for Whom?" Challenges to the School Effectiveness and School Improvement Movements. London: Falmer Press.

Legaard, D.L. 1991. Activities Contributing to School Effectiveness as Perceived by Secondary Principals, Superintendents and Chairpersons of Past NCA Self-Studies (North Central Association).

Lezotte, L. (1989) School improvement based on the effective schools research. International Journal of Educational Research.

Mortimore, P. (1991) The nature and findings of school effectiveness research in the primary sector in S.Riddell \& S. Brown (Eds) School Effectiveness Research: Its Message for School Improvement, London: HMSO.

Mortimore, P. and Whitty, J. (1997) Can School Improvement Overcome the Effects of Disadvantage? London: Institute of Education.

Nuttall, D., Goldstein, H., Prosser, R. and Rasbash, J. (1989) Differential school effectiveness. International Journal of Educational Research.

Retrieved on 17 November, 2011 from http://www.thefreedictionary.com/public+school Retrieved on 31 December, 2011 from http://www.answers.com/topic/private-school

Reynolds, D. et al. (1976a). Schools do Make a Difference. New Society. July 1976. pp.223 - 5.Rosenholtz, S. (1989). Teacher's Workplace: The Social Organization of Schools. New York, Longman.

Role of Teacher in School Effectiveness. Retrieved on 16 March, 2011 from http://www.highreliability.co.uk/Shared /TeacherEffectiveness.aspx

Rutter, M., Maugham, B., Mortimore, P. and Ouston, J. (1979) Fifteen Thousands Hours: Secondary Schools and Their Effects on Children. London: Open Books.

Sammons. P., Hillman, J. and Mortimore, P. 1995. Key Characteristics of Effective Schools. London : Office for Standards in Education. NCE.

Scheerens, J. (2001) Effectiveness Schooling: Research, Theory and Practice, London: Cassell. Secondary School. Retrieved on 5 January, 2011 from http://www.thefreedictionary.com/secondary+school

Siddiqui, S. (2007). Rethinking Education in Pakistan ; Perspectives, Practice, \& Possibilities. Karachi; Paramount Publishing Enterprise.

Stenhouse, L. (1975). An Introduction to Curriculum Research and Development.London, Heinemann Educational Books.

Stoll, L. and Fink, D. (1996) Changing Our Schools: Linking School Effectiveness and School Improvement. Buckingham: Open University Press.

Stoll, L., \& Fink, D. (1999). Changing our schools: Linking school effectiveness and school improvement. Buckingham, PA: Open University Press.

The Processes of Effective Schools. Retrieved on 2 April, 2012 from http://www.cfbt.com/evidenceforeducation/pdf IFull\%20Literature\%20Review.pdf

Thomas, S.2001.Dimensions of Secondary School Effectiveness: Comparative Analyses Across Regions. School Effectiveness and School Improvement.

Townsend, T., Clarke, P., and Ainscow, M (1999) Third MilleniumSchools. A world of difference in effectiveness and improvement. The Netherlands: Swets and Zeitlinger.

West, A., 1999, Vocational education and training indicators project EU priorities and objectives related to VET, November (European Commission, European Centre for the Development of Vocational Training (Cedefop)).

Wikeley, F. (1998) Dissemination of Research: A tool for School Improvement? School leadership and Management.

Wilson, B. L. and T. B. Corcoran. (1988). Successful Secondary Schools. Lewes, Falmer Press. 